\title{
Effect of Chronic Regular Swimming Exercise on Thyroid Function in Ovariectomized Rats
}

\author{
MERVAT H. EL-SAKA, M.D.*; NERMIN M. MADI, M.D.* and HALA E. METWALI, M.D.** \\ The Departments of Physiology* and Biochemistry**, Faculty of Medicine, Tanta University, Egypt
}

\begin{abstract}
Background: Thyroid dysfunction may occur in women in menopausal period or after ovariectomy. Effect of exercise on thyroid function remains controversial and need more investigations.
\end{abstract}

Aim of Study: This study was done to investigate the effect of chronic regular swimming exercise on thyroid function in ovariectomized rats.

Material and Methods: Rats were divided into 6 groups (7 rats per each); Sham-operated sedentary (sham-S) group, (2) Sham-operated with swimming exercise training (sham + Ex) group, (3) Ovariectomized sedentary (OVX-S) group, (4) OVX-group with swimming exercise training $(\mathrm{OVX}+\mathrm{Ex})$, (5) OVX-group injected with 17- $\beta$ estradiol (OVX $+\mathrm{E}),(6)$ OVX-group with swimming exercise training and injected with 17-R estradiol $(\mathrm{OVX}+\mathrm{Ex}+\mathrm{E}) .3$ months after the surgery, rats were exposed to the exercise protocol for another 3 months. BMI was calculated. At the end experimental period, the serum levels of $\mathrm{T}_{3}, \mathrm{~T}_{4}$, TSH, estradiol and interleukin- 6 (IL-6) were determined. The thyroid glands were weighed. The histopathological examination of thyroid tissue was done for determination of epithelial cell height, follicular and colloidal areas.

Results: In OVX-S group, final BMI was significantly increased, serum levels of $\mathrm{T}_{3}$ and $\mathrm{T}_{4}$ were significantly decreased with significant increase of serum TSH level as compared with Sham-S group. While, as compared to OVX$\mathrm{S}$ group, final BMI was significantly decreased, $\mathrm{T}_{3}$ and $\mathrm{T}_{4}$ levels were significantly increased with decrease of TSH level in OVX-treated groups. Estradiol level was significantly decreased in OVX-S group compared to sham-S group. While, in comparison with OVX-S group, its level significantly increased in OVX-treated groups. Serum IL-6 was insignificant changed between Sham-S, OVX-S and OVX + E groups. But, it significantly increased in Sham-Ex, OVX + Ex and OVX $+\mathrm{Ex}+\mathrm{E}$ groups as compared to Sham-S, OVX-S and OVX + E groups. Histopathological examination showed significant decrease of the thyroid gland weight and height of epithelial cells, with significant increase in the follicular and colloidal areas in the OVX-S group as compared to sham-S group. These histopathological changes were improved in OVXtreated groups.

Correspondence to: Dr. Mervat H. El-Saka, E-Mail: tantaphysiology@yahoo.com
Conclusion: We concluded that regular swimming exercise in OVX-rats ameliorated the thyroid hypofunction which may be related to its ability to increase estradiol level in these rats.

Key Words: Swimming exercise - Thyroid function - Ovariectomized rats $-17-\beta$ estradiol.

\section{Introduction}

MENOPAUSE is a natural event in women which represents the end of the reproductive period of women [1]. It is characterized by dramatic reduction of the circulating estrogen [2]. Ovariectomized $(\mathrm{OVX})$ animals could be used as models for menopause with reduced estrogen functions [3]. Estrogen has an important role in regulation of the functions of organs including the thyroid gland [4]

There are some clinical studies have been proved that the reduction of the circulating estrogen levels in menopause or after ovariectomy led to dysfunction of the thyroid gland $[\mathbf{5 , 6}]$. This dysfunction may include hyper or hypothyroidism, and autoimmune thyroiditis, which are the most common disorders in postmenopausal period [7] Estrogen therapy, in postmenopausal women, alleviates the menopausal symptoms as insomnia, hot flashes, and prevents osteoporosis [8]. Some studies have demonstrated that estrogen treatment in menopausal period activates the pituitary-thyroid axis [9].However, hormonal replacement therapy may have adverse effects as incidence of breast cancer

Some previous studies demonstrated that exercise might enhance the function of the thyroid gland [11]. Several studies have reported that the physical exercise could increase the circulating estrogen levels in postmenopausal women $[\mathbf{1 2 , 1 3}$ and OVX rats [14].

Effect of exercise on the thyroid hormones remains controversial. Some studies have reported 
that exercise has no effect on the thyroid hormones levels [15], other researches demonstrated that exercise significantly reduced thyroid hormones levels [16]. While, other reports showed increase in the levels of these hormones in response to exercise [17]. These contradictory results may be due to the difference in the protocols of exercise intensity or difference in the time of evaluation of the humans or animals after exercise [18]

Although, there were numerous previous studies aiming to evaluate the effect of exercise on thyroid function. But, there has been no study investigating the effect of regular exercise on the thyroid function in OVX rat model. So, this study designed to evaluate the effect of chronic regular swimming exercise on thyroid function in ovariectomized rats.

\section{Material and Methods}

\section{Animals:}

This study was carried out on 42 female albino rats of local strain, aged 12-14 weeks, weighing 240-250gm. They were purchased from the Animal House of Tanta University of Medical Sciences. The animals were kept in clean cages, six rats per each cage. The animals allowed free access to water. They received standard diet free from soybean that may affect thyroid function. They were maintained at suitable temperature $\left(24 \pm 2^{\circ} \mathrm{C}\right.$ room temperature) under controlled light dark cycle of $12 \mathrm{~h}$. The animal procedures were approved by Ethical Committee of Faculty of Medicine, Tanta University. The study was done from October 2017 to March 2018.

\section{Experimental design and treatment:}

Rats were randomly divided into 6 groups $(7$ rats per each) as following:

1- Sham-operated sedentary (sham-S) group, (2) Sham-operated with swimming exercise training (sham + Ex) group, (3) Ovariectomized sedentary (OVX-S) group, (4) OVX group with swimming exercise training (OVX + Ex), (5) OVX group injected with $17-\beta$ estradiol $(\mathrm{OVX}+\mathrm{E})$, (6) OVX group with swimming exercise training and injected with $17-\beta$ estradiol $(\mathrm{OVX}+\mathrm{Ex}+$ E).

3 months after surgical procedures, the rats in the groups (Sham-S, Sham+Ex, OVX-S, and OVX + Ex) were injected with sterile olive oil, as a vehicle, $0.1 \mathrm{ml}$ intraperitoneally (i.p.) once daily for 3 months, while the other groups $(\mathrm{OVX}+\mathrm{E}$ and OVX + Ex + E) were injected with 50 1 $\beta$ estadiol i.p. once daily [19] for 3 months. Estradiol was dissolved in $0.1 \mathrm{ml}$ olive oil. It was obtained from Sigma chemical Co.

\section{Surgical procedures:}

All the rats were anaesthetized with phenobarbital sodium $(15 \mathrm{mg} / \mathrm{kg})$ i.p. [20]. In the shamgroups, fat near ovaries were removed instead of the ovaries. The ovaries were only exposed then were replaced in the same position. While, in OVX groups, both ovaries were removed through bilateral skin incision [21]. 3 months after surgery, blood samples were collected from rats for determination of total serum levels of $\mathrm{T}_{3}, \mathrm{~T}_{4}$ concentrations. The rats with euthyroid functions were excluded from the experiment, while rats with thyroid hypofunction were randomly divided into $4 \mathrm{OVX}$ groups as mentioned previously. They are found to be 28 rats with thyroid hypofunction. While, the total number of the OVX rats was 60 rats.

\section{Swimming exercise protocol:}

Three months after the surgery, rats were exposed to the exercise protocol. The exercise protocol consisted of two periods: Adaptation to water period, and exercise period.

- Adaptation to water period: The purpose of this period is adaptation of the rats to water to reduce water stress. This adaptation consisted of exposure of rats to water for 10 minutes at a temperature $\left(30 \pm 1 \mathrm{C}^{\circ}\right)$ daily, for two weeks in a water tank $(80 \mathrm{~cm}$ in length, $50 \mathrm{~cm}$ in width, and $90 \mathrm{~cm}$ in depth) [22].

- Exercise period: In the swimming exercise period, the swimming exercise was performed 5 times/ week for $60 \mathrm{~min} . /$ time for two and half months. The rats swam individually in a water tank. The swimming training was done in water temperature of $\left(30 \pm 1 \mathrm{C}^{\circ}\right.$, between $10-12 \mathrm{~h}$ a.m.) [22]

\section{Body Mass Index (BMI) measurement:}

Body weight of the animals were measured just at the start of the experiment and at the end of the experimental period. The initial and final BMI was calculated by the following equation [23]:

$$
\text { BMI }=\frac{\text { Body weight }(\mathrm{g})}{\text { Length }^{2}\left(\mathrm{~cm}^{2}\right)}
$$

\section{Hormonal assay and biochemical measurements:}

At the end of the experimental period, the animals were scarified by cervical decapitation about 24 hours after final swimming exercise training and/or estradiol treatment to avoid effect of acute stress. The blood samples were collected, then centrifuged at $3000 \mathrm{rpm}$ for 15 minutes. Serum samples were separated and stored at $-20^{\circ} \mathrm{C}$ for 
determination of total $\mathrm{T}_{3}[\mathbf{2 4}], \mathrm{T}_{4}[\mathbf{2 5}], \mathrm{TSH}[26]$ and estradiol [27] levels by Radioimmunoassay (RIA), via using commercial kits. Also, serum level of Interleukin-6 (IL-6) [28] was determined by ELIZA kits.

\section{Histopathological examination:}

The thyroid glands were dissected out, weighed. Then, they were immediately immersed in $4 \%$ formaldehyde solution, embedded in paraffin. They cut longitudinally in $4 \mathrm{msctions,} \mathrm{stained} \mathrm{with}$ hematoxylin and eosin ( $\mathrm{H} \& \mathrm{E})$ to determine morphological changes of thyroid tissue by light microscope [29]. For each sample, the follicular and colloidal areas were determined and the epithelial cell height was measured. The histopathological examination was done at the pathology department of Faculty of Medicine, Kafr El-Sheikh University by an experienced pathologist, who was blinded to the analyzed groups.

\section{Statistical analysis:}

The data were shown as the mean \pm standard deviation. Data from the study were analyzed using one-way ANOVA followed by Tukey's test to assess the significance. The relationship between plasma $\mathrm{BMI}, \mathrm{T}_{3}, \mathrm{~T}_{4}$ and TSH was examined by Pearson's correlation coefficient. $p$-values $<0.05$ were considered statistically significant. All the analyses were performed using SPSS for windows (Version 21.0).

\section{Results}

Initial and final BMI in all studied groups:

As presented in (Table 1) \& Fig. (1): The initial BMI was insignificantly changed between all studied groups. While, at the end of the experiment, the final BMI was significantly increased in OVX$\mathrm{S}$ as compared to sham-S group. There was no significant difference in the final BMI between sham-S and sham-Ex groups. But, as compared to OVX-S group, the final BMI was significantly reduced in OVX-treated groups (OVX + Ex, OVX $+\mathrm{E}$, and $\mathrm{OVX}+\mathrm{Ex}+\mathrm{E})$.
As compared to OVX-S group, the percent decrease of the final BMI was $22.65 \%$ in OVX + Ex group, 3.84\% in OVX + E group, and $23.02 \%$ in $\mathrm{OVX}+\mathrm{Ex}+\mathrm{E}$ group.

As documented in (Table 2), $\mathrm{T}_{3}$ and $\mathrm{T}_{4}$ were negatively correlated with final BMI. However, TSH showed positive correlation with final BMI in OVX-S group and OVX-treated groups.

Table (1): Initial and final BMI in all studied groups.

\begin{tabular}{lcl}
\hline Groups & $\begin{array}{c}\text { Initial BMI } \\
\left(\mathrm{g} / \mathrm{cm}^{2}\right)\end{array}$ & $\begin{array}{c}\text { Final } \mathrm{B}_{2} \mathrm{MI} \\
\left(\mathrm{g} / \mathrm{cm}^{2}\right)\end{array}$ \\
\hline Sham-S group & $0.602 \pm 0.020$ & $0.601 \pm 0.018$ \\
Sham-Ex group & $0.604 \pm 0.021$ & $0.593 \pm 0.016$ \\
OVX-S group & $0.601 \pm 0.019$ & $0.808 \pm 0.011^{\mathbf{a}}$ \\
OVX + Ex group & $0.603 \pm 0.018$ & $0.625 \pm 0.012^{\mathbf{a}^{\prime} \mathbf{b}}$ \\
OVX + E group & $0.595 \pm 0.020$ & $0.777 \pm 0.006^{\mathbf{a}^{\prime} \mathbf{b}} \mathbf{c}$ \\
OVX + Ex + E group & $0.599 \pm 0.017$ & $0.622 \pm 0.008^{\mathbf{b}} \mathbf{d}$ \\
\hline
\end{tabular}

Data are given as mean $\pm \mathrm{SD}$. $a: p<0.05$ vs (sham-S) group. $b: p<0.05$ vs (OVX-S) group. $c: p<0.05$ vs $\mathrm{OVX}+$ Ex group. $d: p<0.05$ vs OVX + E group.

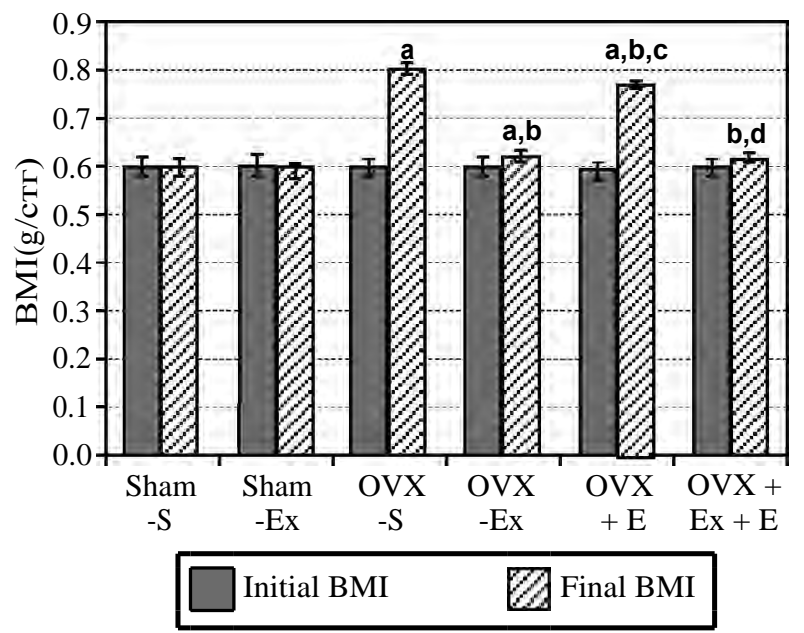

Fig. (1): Initial and final BMI in all studied groups.

Data are given as mean $\pm \mathrm{SD}$ $a: p<0.05$ vs (sham-S) group.

$b: p<0.05$ vs (OVX-S) group. $c: p<0.05$ vs $\mathrm{OVX}+\mathrm{Ex}$ group $d: p<0.05$ vs OVX + E group.

Table (2): Correlation between final BMI and $\mathrm{T}_{3}, \mathrm{~T}_{4}$ and TSH in OVX-S group and OVX-treated groups.

\begin{tabular}{|c|c|c|c|c|c|c|c|c|}
\hline \multirow{3}{*}{ Parameters } & \multicolumn{8}{|c|}{$\mathrm{BMI}\left(\mathrm{g} / \mathrm{cm}^{2}\right)$} \\
\hline & \multicolumn{2}{|c|}{ OVX-S group } & \multicolumn{2}{|c|}{ OVX + Ex group } & \multicolumn{2}{|c|}{$\mathrm{OVX}+\mathrm{E}$ group } & \multicolumn{2}{|c|}{$\mathrm{OVX}+\mathrm{Ex}+\mathrm{E}$ group } \\
\hline & $r$ & $p$-value & $r$ & $p$-value & $r$ & $p$-value & $r$ & $p$-value \\
\hline $\mathrm{T}_{3}(\mathrm{ng} / \mathrm{ml})$ & -0.990 & $0.001^{*}$ & -0.804 & $0.029 *$ & -0.911 & $0.004 *$ & -0.809 & $0.028 *$ \\
\hline $\mathrm{T} 4(\mathrm{ng} / \mathrm{ml})$ & -0.981 & $0.001 *$ & -0.904 & $0.005^{*}$ & -0.896 & $0.006^{*}$ & -0.760 & $0.047 *$ \\
\hline TSH (ng/ml) & 0.983 & $0.001 *$ & 0.926 & $0.003 *$ & 0.779 & $0.039 *$ & 0.894 & $0.007 *$ \\
\hline
\end{tabular}

\footnotetext{
*: Statistically significant.
} 
Serum $T_{3}, T_{4}$ and TSH levels in all studied groups:

These were presented in (Table 3), as regard OVX-S group, serum levels of $\mathrm{T}_{3}$ and $\mathrm{T} 4$ were significantly decreased with concomitant significant increase of serum TSH level as compared with sham-S group. While, as compared to OVX-S group, $\mathrm{T}_{3}$ and $\mathrm{T}_{4}$ levels were significantly increased with concomitant decrease of TSH level in OVXtreated groups $(\mathrm{OVX}+\mathrm{Ex}, \mathrm{OVX}+\mathrm{E}$, and OVX $+\mathrm{Ex}+\mathrm{E})$.

The percent of increase of $\mathrm{T}_{3}$ and $\mathrm{T}_{4}$ in the OVX-treated groups as compared to OVX-S group showed that, it was $53.2 \%$ and $18.8 \%$ for $\mathrm{T}_{3}$ and
$\mathrm{T}_{4}$ respectively in OVX + Ex group, $63.75 \%$ and $44.5 \%$ in OVX + E group, and $74.2 \%$ and $58.5 \%$ in $\mathrm{OVX}+\mathrm{Ex}+\mathrm{E}$ group. While, the percent decrease of TSH was $10.2 \%$ in OVX + Ex group, $27.55 \%$ in OVX + E group, and $33.2 \%$ in OVX + $\mathrm{Ex}+\mathrm{E}$ group as compared to OVX-S group.

It was noticed that, there was insignificant change between Sham-Ex and Sham-S groups. Also, it was observed that as compared to sham$\mathrm{S}$ group, $\mathrm{T}_{3}$ and $\mathrm{T}_{4}$ levels were still significantly lower in OVX + Ex and OVX + E groups than the normal values in sham-S group, but in OVX $+\mathrm{Ex}$ + E group, their levels returned to the normal values.

Table (3): Serum $\mathrm{T}_{3}, \mathrm{~T}_{4}$ and TSH levels in all studied groups.

\begin{tabular}{|c|c|c|c|}
\hline Groups & $\mathrm{T}_{3}(\mathrm{ng} / \mathrm{ml})$ & $\mathrm{T}_{4}(\mathrm{ng} / \mathrm{ml})$ & TSH (ng/ml) \\
\hline Sham-S group & $2.22 \pm 0.11$ & $8.63 \pm 0.30$ & $3.29 \pm 0.14$ \\
\hline Sham-Ex group & $2.27 \pm 0.09$ & $8.69 \pm 0.26$ & $3.31 \pm 0.16$ \\
\hline OVX-S group & $1.24 \pm 0.05^{\mathrm{a}}$ & $5.42 \pm 0.29^{\mathrm{a}}$ & $5.64 \pm 0.14^{\mathrm{a}}$ \\
\hline $\mathrm{OVX}+\mathrm{Ex}$ group & $1.90 \pm 0.06^{\mathbf{a} \cdot \mathbf{b}}$ & $6.44 \pm 0.81^{\mathbf{a}^{\prime} \mathbf{b}}$ & $4.96 \pm 0.13^{\mathbf{a}^{\prime} \mathbf{b}}$ \\
\hline $\mathrm{OVX}+\mathrm{E}$ group & $2.03 \pm 0.05^{a^{\prime}} b^{\prime} c$ & $7.83 \pm 0.49^{\mathbf{a}} \mathbf{b} \mathbf{b}^{\prime} \mathbf{c}$ & $4.09 \pm 0.22^{\mathbf{a}^{\prime} \mathbf{b}^{\prime} \mathbf{c}}$ \\
\hline $\mathrm{OVX}+\mathrm{Ex}+\mathrm{E}$ group & $2.16 \pm 0.07 \mathbf{b}^{\prime} \mathbf{c}^{\prime} \mathbf{d}$ & $8.59 \pm 0.24 \mathbf{b}^{\mathbf{b}^{\prime} \mathbf{c}^{\prime} \mathbf{d}}$ & $3.77 \pm 0.27^{\mathbf{a}} \mathbf{b}^{\prime} \mathbf{c}^{\prime} \mathbf{d}$ \\
\hline
\end{tabular}

\section{Serum estradiol level in all studied groups:}

As shown in Table (4) \& Fig. (2), compared to sham-S group, estradiol level insignificantly changed in sham + Ex group. But, it was significantly decreased in OVX-S group. While, in comparison with OVX-S group, estradiol level significantly increased in OVX + Ex with percent increase $41.95 \%$, in OVX $+\mathrm{E}$ group with percent increase $311 \%$ and also increased in OVX $+\mathrm{Ex}+$ E with percent increase $318.9 \%$. The estradiol level significantly increased in both OVX $+\mathrm{E}$ and OVX $+\mathrm{Ex}+\mathrm{E}$ groups as compared to Sham-S group. There was no significant difference in estradiol

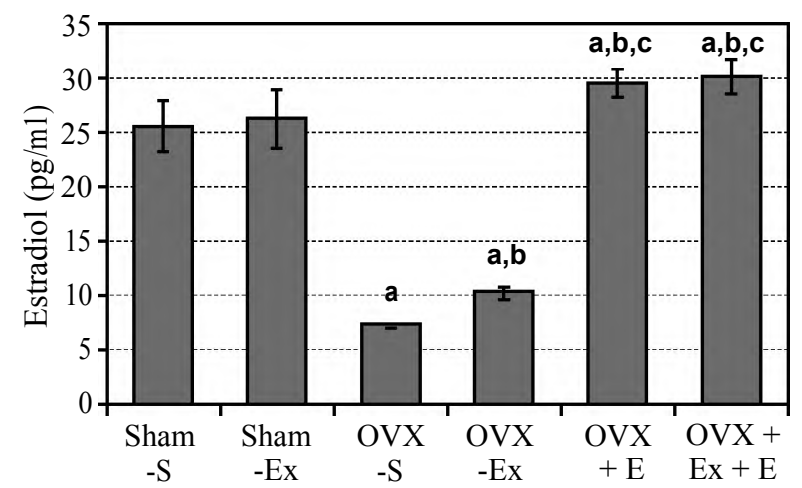

level between both OVX + E group and OVX + $\mathrm{Ex}+\mathrm{E}$ group.

Table (4): Serum estradiol and IL-6 levels in all studied groups.

\begin{tabular}{lll}
\hline Groups & Estradiol $(\mathrm{pg} / \mathrm{ml})$ & IL-6 $(\mathrm{pg} / \mathrm{ml})$ \\
\hline Sham-S group & $25.63 \pm 2.36$ & $23.83 \pm 2.59$ \\
Sham-Ex group & $26.34 \pm 2.63$ & $30.95 \pm 5.39 \mathbf{a}$ \\
OVX-S group & $7.21 \pm 0.06^{\mathbf{a}}$ & $24.61 \pm 2.21$ \\
OVX + Ex group & $10.23 \pm 0.511^{\mathbf{a}, \mathbf{b}}$ & $44.09 \pm 2.79^{\mathbf{a}} \mathbf{b}$ \\
OVX + E group & $29.63 \pm 1.28^{\mathbf{a}} \mathbf{b}^{\prime} \mathbf{c}$ & $24.45 \pm 3.02 \mathbf{c}$ \\
OVX + Ex + E group & $30.20 \pm 1.57^{\mathbf{a}} \mathbf{a}^{\mathbf{b}} \mathbf{c}$ & $45.31 \pm 2.64^{\mathbf{a}} \mathbf{a}^{\prime} \mathbf{b} \mathbf{d}$ \\
\hline
\end{tabular}

Data are given as mean $\pm \mathrm{SD}$ $a: p<0.05$ vs (sham-S) group. $b: p<0.05$ vs (OVX-S) group.

$c: p<0.05$ vs OVX + Ex group $d: p<0.05$ vs OVX + E group.

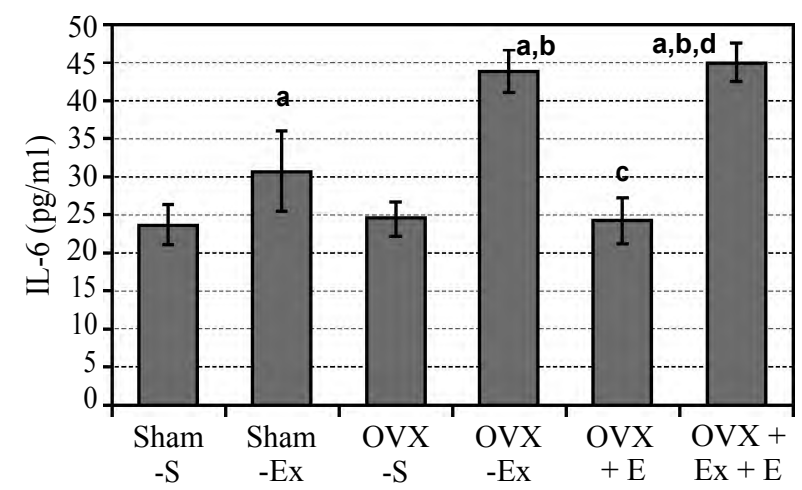

Fig. (2): Serum estradiol and IL-6 levels in all studied groups.

Data are given as mean $\pm \mathrm{SD}$. a: $p<0.05$ vs (sham-S) group. $b: p<0.05$ vs (OVX-S) group. $c: p<0.05 \mathrm{vs}$ OVX + Ex group. $d: p<0.05$ vs OVX + E group. 
Serum IL-6 levels in all studied groups:

As regard serum IL-6, there was no significant difference between Sham-S, OVX-S and OVX + E groups. But, IL-6 level significantly increased in sham-Ex, OVX + Ex and OVX $+\mathrm{Ex}+\mathrm{E}$ groups as compared to Sham-S, OVX-S and OVX $+\mathrm{E}$ groups. There was no significant difference between $\mathrm{OVX}+\mathrm{Ex}$ and $\mathrm{OVX}+\mathrm{Ex}+\mathrm{E}$ groups, (Table 4$)$ \& Fig. (2).

\section{Histopathological evaluation:}

Data belonging the histological changes from thyroid tissue samples were presented in Figs. $(3,4)$ $\&$ (Table 5): The sham-S and sham-Ex groups showed normal histopathological picture of the thyroid gland. While, in OVX-S group, it was noticed that there was significant decrease of the thyroid gland weight and the epithelial cell height, with significant increase of size of follicular areas, and colloidal areas when compared to sham-S group. In OVX-treated groups, it was observed that there was significant increase of the weight of the thyroid gland, and the height of epithelial cells, with concomitant significant decrease of the follicular areas and colloidal areas as compared to OVX-S group. But, these parameters were still significantly changed as compared to sham-S group.

As compared to OVX-S group, the percent increase of the thyroid gland weight was $28.48 \%$ in OVX + Ex group, $53.35 \%$ in Ovx + E group, and $58.88 \%$ in OVX + Ex + E group. As regard the epithelial cell height, the percent increase was $37.3 \%$ in OVX + Ex group, $72.64 \%$ in OVX $+\mathrm{E}$ group, and $83.58 \%$ in OVX $+\mathrm{Ex}+\mathrm{E}$ group as compared to OVX-S group.

Table (5): Thyroid gland weight, and morphological changes in all studied groups.

\begin{tabular}{|c|c|c|c|c|}
\hline Groups & Thyroid weight (gm) & Epithelial cell height ( & Follicular area $\left(\mathrm{m}^{2}\right)$ & Colloidal area $\left(\mathrm{m}^{2}\right)$ \\
\hline Sham-S group & $18.53 \pm 0.77$ & $4.63 \pm 0.35$ & $3.20 \pm 0.28$ & $1.24 \pm 0.16$ \\
\hline Sham-Ex group & $18.55 \pm 0.88$ & $4.48 \pm 0.27$ & $3.33 \pm 0.21$ & $1.17 \pm 0.13$ \\
\hline OVX-S group & $10.64 \pm 0.25^{\mathrm{a}}$ & $2.01 \pm 0.14 \mathrm{a}$ & $5.01 \pm 0.14 \mathrm{a}$ & $3.78 \pm 0.11^{\mathrm{a}}$ \\
\hline OVX + Ex group & $13.67 \pm 0.36^{\mathrm{a} \cdot \mathrm{b}}$ & $2.76 \pm 0.72^{a} b$ & $4.01 \pm 0.07 \mathrm{a}^{\prime} \mathrm{b}$ & $2.72 \pm 0.18 \mathrm{a}, \mathrm{b}$ \\
\hline $\mathrm{OVX}+\mathrm{E}$ group & $16.33 \pm 0.40^{a} b^{\prime} c$ & $3.47 \pm 0.11 \mathrm{a}, \mathrm{b}, \mathrm{c}$ & $3.69 \pm 0.10^{a^{\prime} b^{\prime} c}$ & $1.49 \pm 0.15 \mathrm{a}, \mathrm{b}, \mathrm{c}$ \\
\hline $\mathrm{OVX}+\mathrm{Ex}+\mathrm{E}$ group & $16.90 \pm 0.41 \mathrm{a}, \mathrm{b}, \mathrm{c}$ & $3.69 \pm 0.10 \mathrm{a}, \mathrm{b}, \mathrm{c}$ & $3.45 \pm 0.10 \mathrm{a}, \mathrm{b}, \mathrm{c}$ & $1.42 \pm 0.12^{\mathrm{a}, \mathrm{b}, \mathrm{c}}$ \\
\hline
\end{tabular}

Data are given as mean \pm SD a: $p<0.05$ vs (sham-S) group.
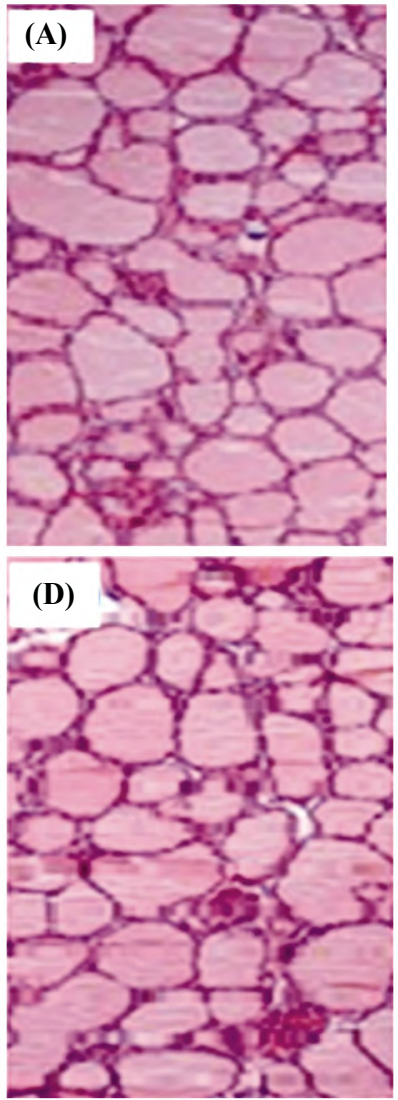
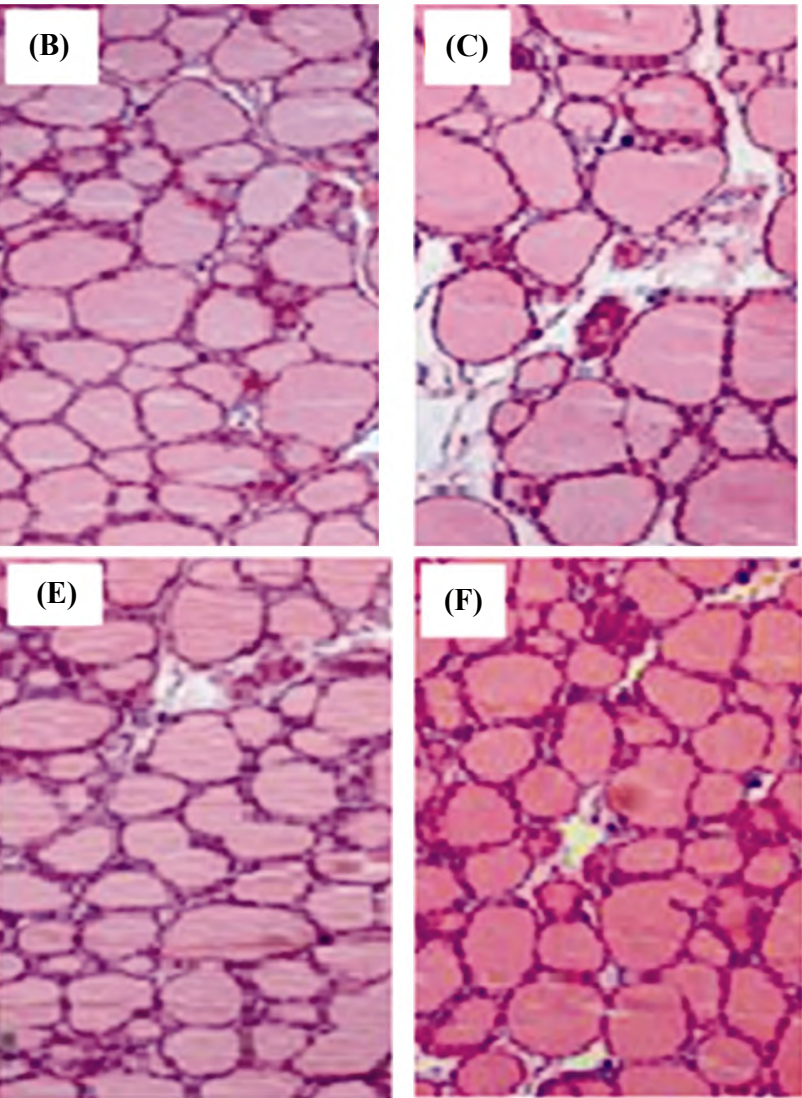

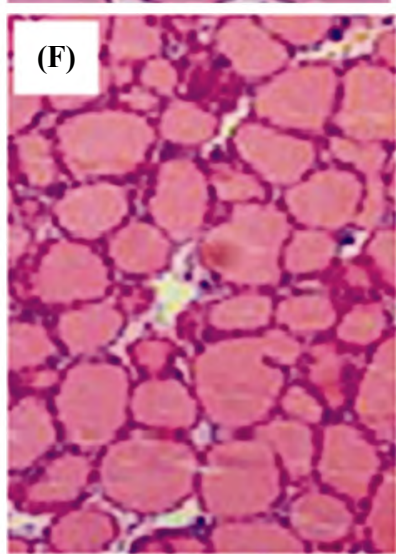

Fig. (3): Histopathological evaluation in all studied groups. Both (A) sham-S group \& (B) sham-Ex groupshowed normal histopathological structure of the thyroid gland. (C) OVX-S group with decreased epithelial cell height, increased follicular and colloidal areas. (D) OVX + EX group, $(\mathrm{E}) \mathrm{OVX}+\mathrm{E}$ group and (F) OVX + EX + E group, respectively showed increased epithelial cell height, decreased follicular and colloidal areas. Magnification H \& E X400. 

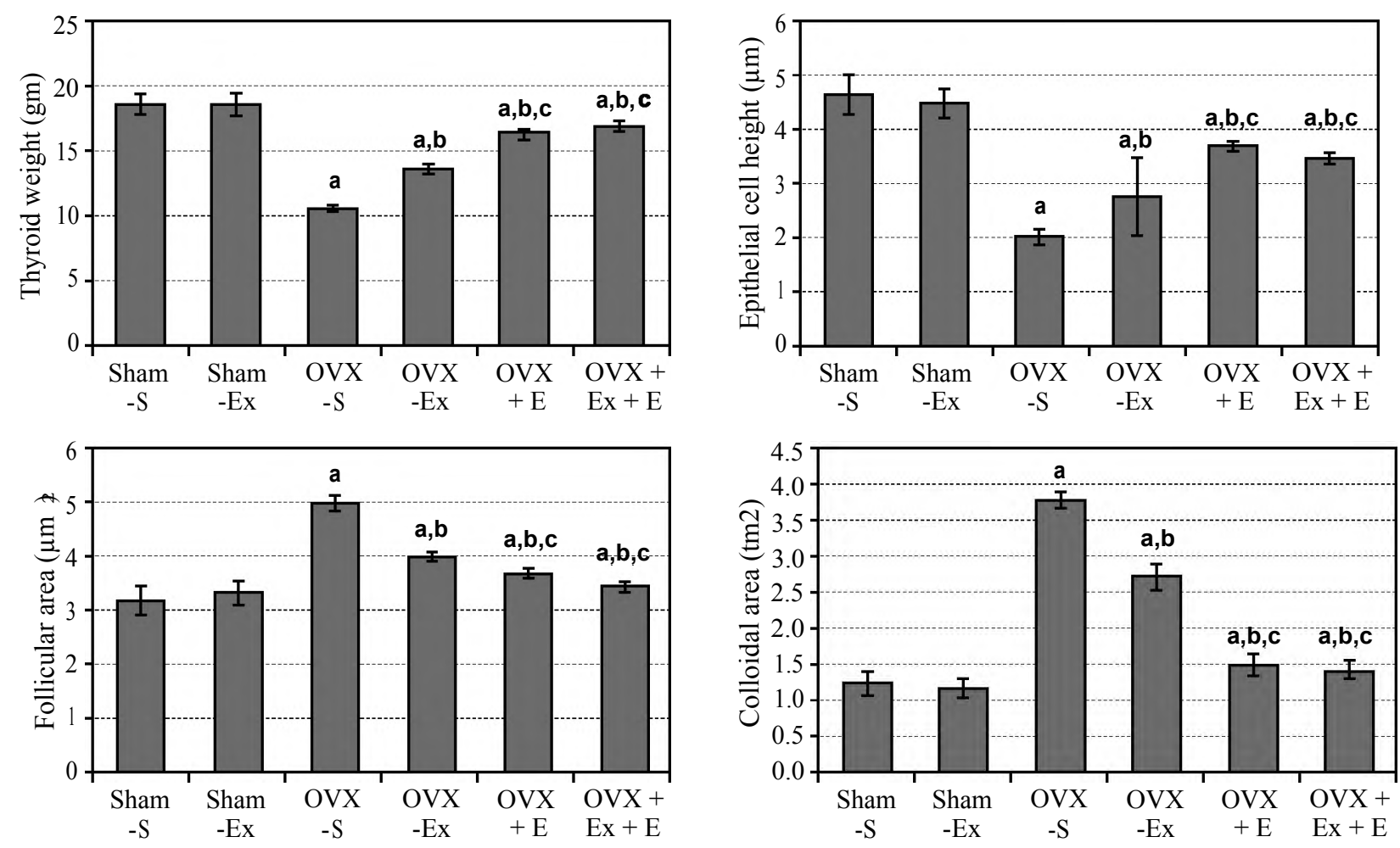

Fig. (4): Thyroid gland weight, and morphological changes in all studied groups.

Data are given as mean $\pm \mathrm{SD}$.

a: $p<0.05$ vs (sham-S) group.

$b: p<0.05$ vs (OVX-S) group.

$c: p<0.05$ vs OVX + Ex group.

$d: p<0.05$ vs OVX + E group.

The percent decrease of the follicular area was $19.96 \%$ in OVX + Ex group, $26.3 \%$ in OVX $+\mathrm{E}$ group, and was $31.1 \%$ in OVX $+\mathrm{Ex}+\mathrm{E}$ group as compared to OVX-S group. While, the percent decrease in the colloidal area was $28 \%$ in OVX + Ex group, $60.58 \%$ in OVX + E group, and $62.40 \%$ in OVX + Ex + E as compared to OVX-S.

\section{Discussion}

The present study showed that the thyroid function significantly impaired in OVX rats as compared to rats with intact ovaries. While, chronic regular swimming exercise and/or estrogen treatment for 3 months after ovariectomy ameliorated the changes in the thyroid function.

It was documented in this study that final BMI was significantly increased in OVX-group as compared to sham-S group. This might be produced as a result of increased food intake and decreased energy expenditure [30]. The increase of BMI following ovariectomy could be explained by decrease in estradiol level [31]. It has been proved that estradiol deficiency leads to increased food intake, although it wasn't estimated in our study. But, it was observed in the previous studies with ovariectomy [32] .
Also, the results of the present study proved that regular swimming exercise and/or estradiol treatment significantly reduced final BMI as compared to OVX-S group. The restoration of body weight and hence BMI in OVX + Ex group might be explained by the direct effect of the exercise itself to increase energy expenditure [33], and also due to increasing estrogen production from extragonadal tissues [34], estrogen acts to prevent increasing BMI via suppressing appetite and increasing the energy expenditure [35].

In the same way, the reduction of BMI in OVX + E group could be explained by estrogen treatment with the previous mentioned effects. It was proved that estradiol administration in OVX-rats increased leptin level and increased its central sensitivity [32]. It has been known that leptin is anorexogenic hormone that suppresses appetite and decreasing body weight [36].

The results of the present study demonstrated that there was significant decrease in the serum levels of $\mathrm{T}_{3}$ and $\mathrm{T}_{4}$ with significant increase in TSH level in OVX-S group as compared with sham-S group. These results were in accordance with Abdel-Dayem and Elgendy [37], who reported decrease of the thyroid function in OVX rats. The 
mechanism that explained the hypofunction of the thyroid gland in OVX-rats still unclear. But, it could be explained by reduction of estrogen level in the OVX-rats. Another explanation was that there might be a link between obesity, that was observed in the OVX-rats as evidenced in our results, and hypothyroidism [38]. There was a previous study suggested that obesity is a risk factor for autoimmune thyroid dysfunction, which is considered to be the main cause for hypothyroidism [39]. This was proved in the results of the present work by the positive correlation between TSH and BMI, while negative correlation between thyroid hormones $\left(\mathrm{T}_{3} \& \mathrm{~T}_{4}\right)$ and BMI.

Our results revealed that both chronic regular swimming exercise and/or estradiol treatment significantly improved the thyroid hypofunction, as evidenced in our results by significant increase of $\mathrm{T}_{3}$ and $\mathrm{T}_{4}$ levels with significant decrease of TSH level when compared with OVX-S group. Also, it was observed that, the percent increase of $\mathrm{T}_{3}$ and $\mathrm{T}_{4}$ levels was more higher after combined exercise training and estradiol treatment than exercise training alone or estradiol treatment alone.

The mechanism by which regular exercise training improved the thyroid function could not be elucidated. But, it might be explained by that exercise training increased serum estradiol level, as evidenced in our study, which in turn affected the thyroid function in OVX-rats. Also, estradiol treatment in OVX-rats improved thyroid function which could be explained by direct effect of estradiol on the thyroid gland due to presence of its receptors in the gland [40]. This also was evidenced by previous studies on thyroid cells in vitro reporting that estrogen had an important role in the proliferation of thyroid cells [41]

The results of the present study demonstrated that in OVX-S group, there was significant reduction of serum estradiol level as compared to the sham-rats. These results were consistent with previous studies showed that serum estrogen level decreased after ovariectomy [42]

Also, the results of the present study proved that this reduction was reversed by regular swimming exercise training and/or estradiol treatment. Also, a number of previous findings supported our results that exercise could increase serum estrogen level in OVX-rats [43] . However, some clinical reports found that estrogen levels were insignificantly changed in response to exercise [44]. These contradictory results might be caused by the difference in the age of patients or animals and the difference in the exercise intensity [45]. The mechanism by which regular exercise training increased serum estradiol level in OVX-rats was unknown and needed further investigations. But, it could be explained by extragonadal synthesis of estadiol in OVX-rats following regular swimming exercise [34].

Estradiol is considered one of steroid hormones, its synthesis could be mediated by IL-6 [43]. The later might be produced by muscles during exercise [46]. When IL-6 increases in the circulation, it will be able to increase aromatase activity in extragonadal sites as adrenal cortex, adipose tissue and bone [47].

The present study revealed that the serum level of IL-6 significantly increased only in sham-Ex and OVX rats after chronic regular swimming exercise training alone or when combined with estradiol treatment as compared to OVX-S rats and sham-S group. The increased level of IL- 6 after exercise training in sham-Ex and OVX-rats could be explained by its production by the muscles during exercise [46]. Hence, the increased levels of serum IL-6 in OVX-groups after exercise could explained the increase serum estardiol level in these groups.

Also, histopathological data from the results of our study indicated that in OVX-S group, the thyroid gland weight significantly decreased with decrease in the height of epithelial cells. While, the follicular and colloidal areas were significantly increased which confirmed the hypoactivity and hypofunction of the thyroid gland evidenced by biochemical analysis. These histopathological changes were attenuated by chronic regular swimming exercise and/or estradiol treatment.

From all the previous biochemical and histopathological results, it was observed that combination of exercise training with estradiol treatment were more efficient than exercise or estradiol treatment alone.

\section{Conclusion:}

We observed that ovariectomy caused thyroid hypofunction in rats with significant decrease of estradiol level. While, chronic regular swimming exercise significantly improved the thyroid function with significant increase of estradiol level. These findings were of great interest as they clarified the possible beneficial effect of regular exercise in postmenopausal period on thyroid function, which can be combined or replace the hormonal replacement therapy with estrogen in this period of life 
with multiple hazards of estrogen. So, further investigations for the effect of regular exercise in women in menopausal period were needed. Also, further investigations will be needed to clarify the possible mechanisms for the effects of exercise on thyroid functions in postmenopausal period.

\section{Acknowledgment:}

Great thanks to Prof. Dr. Eman El-Saed, professor of pathology, Faculty of Medicine, Kafr ElSheikh University, for her help in the histopathological part of this study.

\section{References}

1- HOYT L.T. and FALCONI A.M.: Puberty and perimenopause: reproductive transitions and their implications for women's health. Soc. Sci. Med., 132: 103-12, 2015.

2- SANTORO N. and RANDOLPH J.F.: Reproductive hormones and the menopause transition. Obstet. Gynecol. Clin. North Am., 38 (3): 455-66, 2011.

3- MERCANTEPE T., UNAL D., SELLI J., MERCANTEPE F., UNAL B. and KARABIYIK T.N.: Protective effects of estrogen and bortezomib in kidney tissue of postmenopausal rats: An ultrastructural study. Ren. Fail., 38 (7): 1129-35, 2016.

4- SANTIN A.P. and FURLANETTO T.W.: Role of estrogen in thyroid function and growth regulation.J Thyroid Res. 2011:875125, 2011.

5. CHON S.J., HEO J.Y., YUN B.H., JUNG Y.S., and SEO S.K.: Serum thyroid stimulating hormone levels are associated with the presence of coronary atherosclerosis in healthy postmenopausal women. J. Menopausal. Med., 22 (3): 146-53, 2016.

6- BREMNER A.P., FEDDEMA P., LEEDMAN P.J., BROWN S.J., BEILBY J.P., LIM E.M., et al.: Age-related changes in thyroid function: A longitudinal study of a community-based cohort. J. Clin. Endocrinol. Metab., 97 (5): 1554-62, 2012.

7- GIETKA-CZERNEL M.: The thyroid gland in postmenopausal women: Physiology and diseases. Prz Menopauzalny, 16 (2): 33-7, 2017.

8- MARJORIBANKS J., FARQUHAR C., ROBERTS H., LETHABY A. and LEE J.: Long-term hormone therapy for perimenopausal and postmenopausal women. Cochrane Database Syst. Rev., 1: CD004143, 2017.

9- KORDI F. and KHAZALI H.: The effect of ghrelin and estradiol on mean concentration of thyroid hormones. Int. J. Endocrinol. Metab., 13 (1): e17988, 2015.

10- CORDINA-DUVERGER E., TRUONG T., ANGER A., SANCHEZ M., ARVEUX P., KERBRAT P., et al.: Risk of breast cancer by type of menopausal hormone therapy: A case-control study among post-menopausal women in France. PLoS One, 8 (11): e78016, 2013.

11- BANSAL A., KAUSHIK A., SINGH C.M., SHARMA V., and SINGH H.: The effect of regular physical exercise on the thyroid function of treated hypothyroid patients: An interventional study at a tertiary care center in Bastar region of India. Arch. Med. Health Sci., 3: 244-6, 2015.
12- MCTIERNAN A., TWOROGER S.S., ULRICH C.M., YASUI Y., IRWIN M.L., RAJAN K.B., et al.: Effect of exercise on serum estrogens in postmenopausal women: a 12-month randomized clinical trial. Cancer Res., 64 (8): 2923-8, 2004.

13- FRIEDENREICH C.M., NEILSON H.K., WANG Q., STANCZYK F.Z., YASUI Y., DUHA A., et al.: Effects of exercise dose on endogenous estrogens in postmenopausal women: A randomized trial. Endocr. Relat. Cancer, 22 (5): 863-76, 2015.

14- MACDONALD T.L., RITCHIE K.L., DAVIES S., HAMILTON M.J., CERVONE D.T. and DYCK D.J.: Exercise training is an effective alternative to estrogen supplementation for improving glucose homeostasis in ovariectomized rats. Physiol. Rep., 3 (11). PII: e12617, 2015.

15- ONSORI M. and GALEDARI M.: Effects of 12 weeks aerobic exercise on plasma level of TSH and thyroid hormones in sedentary women. Euro. J. Sports Exerc. Sci., 4 (1): 45-9, 2015.

16- CILOGLU F., PEKER I., PEHLIVAN A., KARACABEY K., ILHAN N., SAYGIN O., et al.: Exercise intensity and its effects on thyroid hormones. Neuro. Endocrinol. Lett., 26 (6): 830-4, 2005.

17- HACKNEY A.C., KALLMAN A., HOSICK K.P., RUBIN D.A., and BATTAGLINI C.L.: Thyroid hormonal responses to intensive interval versus steady-state endurance exercise sessions. Hormones (Athens), 11 (1): 54-60, 2012.

18- FORTUNATO R.S., IGNACIO D.L., PADRON A.S., PEÇANHA R., MARASSI M.P., ROSENTHAL D. et al.: The effect of acute exercise session on thyroid hormone economy in rats. J. Endocrinol., 198 (2): 347-53, 2008.

19- HAO L., WANG Y., DUAN Y. and BU S.: Effects of treadmill exercise training on liver fat accumulation and estrogen receptor alpha expression in intact and ovariectomized rats with or without estrogen replacement treatment. Eur. J. Appl. Physiol., 109 (5): 879-86, 2010.

20- PANTALEAO T.U., MOUSOVICH F., ROSENTHAL D., PADRON A.S., CARVALHO D.P., and DA COSTA VM.: Effect of serum estradiol and leptin levels on thyroid function, food intake and body weight gain in female Wistar rats. Steroids, 75 (10): 638-42, 2010.

21- MOHAMED M.K. and ABD EL-RAHMAN A.A.: Effect of long-term ovariectomy and estrogen replacement on the expression of estrogen receptor gene in female rats. Eur. J. Endocrinol., 142 (3): 307-14, 2000.

22- CARDOSO A.M., ABDALLA F.H., BAGATINI M.D., MARTINS C.C., FIORIN FDA S., BALDISSARELLI J., et al.: Swimming training prevents alterations in acetylcholinesterase and butyrylcholinesterase activities in hypertensive rats. Am. J. Hypertens, 27 (4): 522-9, 2014.

23- ENGELBREGT M.J., VAN WEISSENBRUCH M.M., POPP-SNIJDERS C., LIPS P., and DELEMARRE-VAN DE WAAL H.A.: Body mass index, body composition, and leptin at onset of puberty in male and female rats after intrauterine growth retardation and after early postnatal food restriction. Pediatr. Res., 50 (4): 474-8, 2001.

24- KLEE G.G.: Clinical usage recommendations and analytic performance goals for total and free triiodothyronine measurements. Clin. Chem., 42 (1): 155-9, 1996. 
25- NELSON J.C. and WILCOX R.B.: Analytical performance of free and total thyroxin assays. Clin Chem., 42 (1): 146$54,1996$.

26. HOOD A., LIU Y.P., GATTONE V.H., and KLAASSEN C.D.: Sensitivity of thyroid gland growth to thyroid stimulating hormone. Toxicol. Sci., 49 (2): 263-71, 1999.

27- HAISENLEDER D.J., SCHOENFELDER A.H., MARCINKO E.S., GEDDIS L.M. and MARSHALL J.C.: Estimation of estradiol in mouse serum samples: Evaluation of commercial estradiol immunoassays. Endocrinology, 152 (11): 4443-7, 2011.

28- SCHEFOLD J.C., HASPER D., VON HAEHLING S., MEISEL C., REINKE P. and SCHLOSSER H.G.: Interleukin-6 serum level assessment using a new qualitative point-of-care test in sepsis: A comparison with ELISA measurements. Clin. Biochem., 41 (10-11): 893-8, 2008.

29- RAJKOVIC V., MATAVULJ M. and JOHANSSON O. Light and electron microscopic study of the thyroid gland in rats exposed to power-frequency electromagnetic fields. J. Exp. Biol., 209 (Pt 17): 3322-8, 2006.

30- GILES E.D., JACKMAN M.R., JOHNSON G.C., SCHEDIN P.J., HOUSER J.L., and MACLEAN P.S.: Effect of the estrous cycle and surgical ovariectomy on energy balance, fuel utilization, and physical activity in lean and obese female rats. Am. J. Physiol. Regul. Integr. Comp. Physiol., 299 (6): R1634-42, 2010.

31- SPRINGER A.M., FOSTER-SCHUBERT K., MORTON G.J., and SCHUR E.A.: Is there evidence that estrogen therapy promotes weight maintenance via effects on leptin? Menopause, 21 (4): 424-32, 2014.

32- FUNGFUANG W., TERADA M., KOMATSU N., MOON C. and SAITO T.R.: Effects of estrogen on food intake, serum leptin levels and leptin mRNA expression in adipose tissue of female rats. Lab. Anim. Res., 29 (3): 168-73, 2013.

33- EKELUND U., FRANKS P.W., SHARP S., BRAGE S., and WAREHAM N.J.: Increase in physical activity energy expenditure is associated with reduced metabolic risk independent of change in fatness and fitness. Diabetes Care, 30 (8): 2101-6, 2007.

34- RAUF S., KSOEJONO S. and PARTADIREDJA G.: Effects of treadmill exercise training on cerebellar estrogen and estrogen receptors, serum estrogen, and motor coordination performance of ovariectomized rats. Iran J. Basic Med. Sci., 18 (6): 587-92, 2015.

35- SCHMIDT S.1., MONK J.M., ROBINSON L.E. and MOURTZAKIS M.: The integrative role of leptin, oestrogen and the insulin family in obesity-associated breast cancer: Potential effects of exercise. Obes. Rev., 16 (6): 473-87, 2015
36- MELBY C.L., PARIS H.L., FORIGHT R.M. and PETH $\mathrm{J}$.: Attenuating the biologic drive for weight regain following weight loss: Must what goes down always go back up? Nutrients, 9 (5) pii: E468, 2017.

37- ABDEL-DAYEM M.M. and ELGENDY M.S.: Effects of chronic estradiol treatment on the thyroid gland structure and function of ovariectomized rats. B.M.C. Res. Notes, 2: 173, 2009.

38- SANYAL D., and RAYCHAUDHURI M.: Hypothyroidism and obesity: An intriguing link. Indian J. Endocrinol. Metab., 20 (4): 554-7, 2016.

39- LONGHI S. and RADETTI G.: Thyroid function and obesity. J. Clin. Res. Pediatr. Endocrinol., 5 (Suppl 1): 40-4, 2013.

40- SANTIN A.P., and FURLANETTO T.W.: Role of estrogen in thyroid function and growth regulation. J. Thyroid. Res., 2011: 875125, 2011

41- HIMA S., and SREEJA S.: Modulatory role of 17 estradiol in the tumor microenvironment of thyroid cancer. I.U.B.M.B. Life, 68 (2): 85-96, 2016.

42- STROM J.O., THEODORSSON A., INGBERG E., ISAKSSON I.M., and THEODORSSON E.: Ovariectomy and $17 \beta$-estradiol replacement in rats and mice: A visual demonstration. J. Vis. Exp., 64: e4013, 2012.

43- LI L., CHEN X., LV S., DONG M., ZHANG L., TU J., et al.: Influence of exercise on bone remodeling-related hormones and cytokines in ovariectomized rats: A model of postmenopausal osteoporosis. PLoS One, 9 (11): e112845, 2014

44- SMITH A.J., PHIPPS W.R., ARIKAWA A.Y., O'DOUGHERTY M., KAUFMAN B., THOMAS W., et al.: Effects of aerobic exercise on premenopausal sex hormone levels: Results of the WISER study, a randomized clinical trial in healthy, sedentary, eumenorrheic women. Cancer Epidemiol, Biomarkers Prev., 20 (6): 1098-106, 2011.

45- SMITH A.J., PHIPPS W.R., THOMAS W., SCHMITZ K.H., and KURZER M.S.: The effects of aerobic exercise on estrogen metabolism in healthy premenopausal women. Cancer Epidemiol Biomarkers Prev., 22 (5): 756-64, 2013.

46- KIM K.B.: Effect of different training mode on Interleukin6 (IL-6) and C-reactive protein (CRP) in type 2 diabetes mellitus (T2DM) patients. J. Exerc. Nutrition Biochem, 18 (4): 371-8, 2014.

47- ZHAO H., ZHOU L., SHANGGUAN A.J., and BULUN S.E.: Aromatase expression and regulation in breast and endometrial cancer. J. Mol. Endocrinol., 57 (1): R19-33, 2016. 


\section{تآثير الممارسة الهنتظمة لرياضة السباحة على المئى عمل الغلدة الدرقية

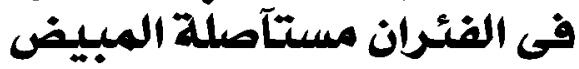

هدف البحث: يهدف هذا البحث إلى دراسة تآثير الممارسة المنتظمة لرياضة السباحة على وظيفة الفدة الدرقية فى الفئران المستآصلة

$$
\begin{aligned}
& \text { الطريقة: تم تقسيم الفئران إلى ست مجموعات تحتوى كل مجموعة على سبع فئران: } \\
& \text { • المجموعة الأولى (المجموعة الضابطة): تم إجراء لها عملية جراحية خادعة ولا تمارس الرياضة. } \\
& \text { • المجموعة الثانية: تم إجراء لها عملية جراحية خادعة وتمارس رياضة السباحة. } \\
& \text { • المجموعة الثالثة: تم إستئصال المبيض فيها مع علم ممارسة رياضة السباحة. } \\
& \text { • المجموعة الرابعة: تم إستئهال المبيض فيها مع ممارسة رياضة السباحة. } \\
& \text { • المجموعة الخامسة: تم إستئصال المبيض فيها مع الحقن ب لابيتا استراديول. } \\
& \text { • المجموعة العـادسة: تم إستئصال المبيض فيها مع الحقن ب IV بيتا استراديول وتمارس رياضة السباحة. }
\end{aligned}
$$

وفى نهاية فترة الدراسة تم تجميع العيرم من الفئران لقياس نسبة ثلاثى يودوثيرنين ودباعى يودوثيرونين والهرمون المحفز اللغدة الدرقية

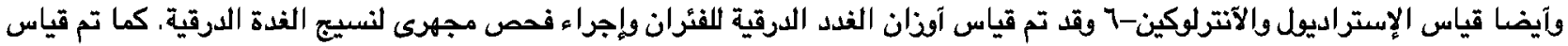
مؤشر ونت الجسم.

النتائج: آظهرت النتائج آن مؤثر ونت الجسم زاد زيادة ذات دلالة إحصائية في المجموعة الثالثة بالمقارنة بالمجموعة الضابطة، في حين

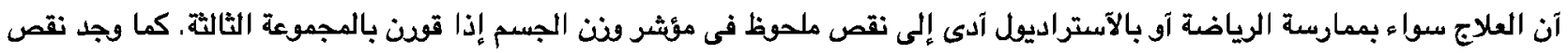

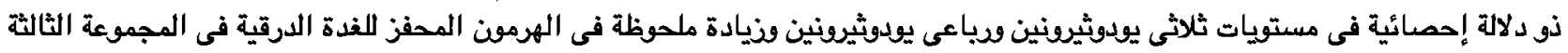

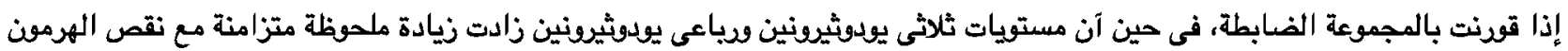

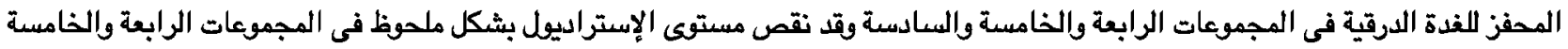

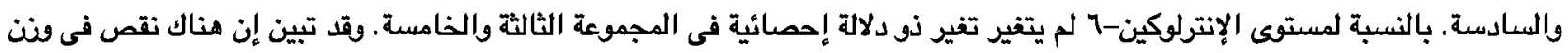

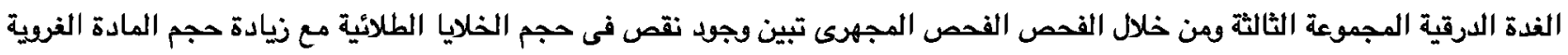
بهذه المجموعة وقد تحسنت هذه المتغيرات مع تلقى العلاج سواء بممارسة الرياضة آو بالإستراديول. الختلاصة: نستخلص من كل ما سبق إن الممارسة المستمرة لرياضة السباحة فى الفئران المستآصل مبيضها آدت إلى تحسن فى آداء الفدة الدرقية وذلك يمكن تفسيره بزيادة إفراز الإستراديول في هذ هذه الفئئ هئران. 